\title{
Borders: Terminologies, Ideologies, and Performances
}

\section{Ed. by Annette Weissenrieder}

[Grenzen: Terminologien, Ideologien und Eigenschaften.]

Veröffentlicht auf Englisch.

Welche relevanten Konzepte und Terminologien kennzeichnen politische, kultische und religiöse Grenzen und Grenzbereiche bzw. Randzonen und was genau bezeichnen diese in der Antike? In diesem Sammelband erforscht eine internationale Gruppe von Archäologen, Altphilologen, Historikern und biblischen Exegeten Begriffe, Performanz und Ideologien von Grenzen in der Antike. Der primäre Fokus des Sammelbandes liegt auf den physischen Grenzen und Randzonen von politischen Organisationen wie auch von Tempeln und Häusern, die in Demarkationslinien im religiösen Leben in der Antike erfahrbar sind. Zudem werden grenzüberschreitende soziale Bezüge anhand archäologischer Funde und Textquellen untersucht und ihre Bedeutung für einen kulturellen und religiösen Transfer aufgezeigt.

Inhaltsübersicht

Introduction

I. Borders, Frontiers, and Boundaries of Land and City: Terms, Performances and Ideologies

Annette Schellenberg: »And God Separated the Light from the Darkness « (Gen 1:4) - On the Role of Borders in the Priestly Texts of the Pentateuch - Martina Kepper: What to Do with Borders When They Become Obsolete? Strategies of Re-defining Border Concepts in the Greek Text of Genesis - David L. Balch: Borders: Terms, Ideologies, and Performances. Jesus and the Samaritan/Judean Border - Harry O. Maier: Histoire Croisée, Entangled Bodies, Boundaries, and Socio-Political Geography in the Letter to the Colossians - Alexander Sokolicek: Betwixt and Between - The Cultural Roles of the Magnesian Gate in GreekRoman Ephesus - Christine M. Thomas: The Magnesian Gate at Ephesos: Variant Readings of Monumentality at the Borders of the City - Stephan Esders: Deditio and Baptism: Religious Borders and the Integration of Barbarians in the Later Roman Empire - Susanna Elm: Response to Stefan Esders: Deditio and Baptism

\section{Borders and Boundaries of Temples: Terms, Performances, and Ideologies}

Barbara Schmitz: Space, Borders and Boundaries in the Letter of Aristeas - Georgia Petridou: Amorphous Epiphanies and Divine Bilingualism: Crossing Physical and Cultural Borders on the Battlefield - Anna-Katharina Rieger: Gods on the Rocks Material Approaches to the Rock-Face at Caesarea Philippi (Mount Hermon) - Annette Weissenrieder: »Tear Down the Middle Wall of the Temple«: The Meaning of mesotoichon in Ephesians 2:14

III. Borders and Boundaries of Houses: Terms, Performances, and Ideologies Frank Ueberschaer: Borders between Privacy and Public in the Thinking of Ben Sira - Bart Bruehler: Open and Shut: The Real and Metaphorical Doors of the New Testament in their Mediterranean Context - Ivan Varriale: Otium and negotium, a Border Breaks Down in the Imperial Villas. The study case of Pausilypon

\section{Borders and Boundaries}

Barbara Böck: On the Ancient Mesopotamian Concept of »Taboo«: Transgression and Delimitation - Ingrid Lilly: Rûah Embodied: Job's Internal Disease from the Perspective of Mesopotamian Medicine - Gert J. Steyn: Crossing the Border Reflections on Heb 13:13. "Let us then go to him outside the camp...«-Michael Bachmann: Important and Delicate: Borders According to Paul - James R. Harrison: Who is the "Lord of Grace«? Jesus' Parables in Imperial Context - Holger Zellentin: Jewish Dreams Between Roman Palestine and Sasanian Babylonia: Cultural and Geographic Borders in Rabbinic Discourse (Yerushalmi Ma'aser Sheni 55c, 15-22 and Bavli Berakhot 56a-b)

Annette Weissenrieder Born 1967; Professor of Exegesis and Theology of New Testament at the Faculty of Theology at the Martin-Luther-University and director of the Institute »Corpus Hellenisticum«, University of Halle-Wittenberg.

Jetzt bestellen:

https://mohrsiebeck.com/buch/borders-terminologies-ideologies-and-performances-9783161543760?no_cache=1 order@mohrsiebeck.com

Telefon: +49 (0)7071-923-17

Telefax: $+49(0) 7071-51104$ 